\title{
Biomarkers in Patients with Metastatic Breast Cancer and the PRAEGNANT Study Network
}

\author{
Biomarker für Patientinnen mit metastasiertem Mammakarzinom \\ und das PRAEGNANT-Studiennetzwerk
}

Authors

Affiliations
P. A. Fasching ${ }^{1,17 *}$, S. Y. Brucker ${ }^{3,17 *}$, T. N. Fehm ${ }^{4}$, F. Overkamp ${ }^{5}$, W. Janni ${ }^{6}$, M. Wallwiener $^{7}$, P. Hadji ${ }^{8}$, E. Belleville ${ }^{9}$, L. Häberle ${ }^{1,10}$, F.-A. Taran ${ }^{2}$, D. Lüftner ${ }^{11}$, M. P. Lux ${ }^{1}$, J. Ett| ${ }^{12}$, V. Müller ${ }^{13}$, H. Tesch $^{14,15}$, D. Wallwiener ${ }^{2,15}$, A. Schneeweiss ${ }^{6,16}$

The affiliations are listed at the end of the article.

\section{Key words \\ - breast cancer \\ - metastasis \\ - PRAEGNANT \\ - mutation \\ - biomarker \\ - prognosis}

\section{Schlüsselwörter}

- Brustkrebs

- Metastasen

- PRAEGNANT

- Mutation

- Biomarker

- Prognose

Deutschsprachige Zusatzinformationen online abrufbar unter: www.thieme-connect.de/ ejournals/toc/gebfra

\section{received $\quad 30.12 .2014$ \\ revised $\quad 5.1 .2015$ \\ accepted 6.1.2015}

Bibliography

Dol http://dx.doi.org/

10.1055/s-0034-1396215

Geburtsh Frauenheilk 2015; 75 :

41-50 ๑ Georg Thieme

Verlag KG Stuttgart · New York .

ISSN 0016-5751

\section{Correspondence}

Prof. Peter A. Fasching, MD

University Hospital Erlangen

Department of Gynecology

and Obstetrics

Universitätsstraße 21-23

91054 Erlangen

peter.fasching@uk-erlangen.de

\section{Abstract \\ $\nabla$}

Progress has been made in the treatment of metastatic breast cancer in recent decades, but very few therapies use patient or tumor-specific characteristics to tailor individualized treatment. More than ten years after the publication of the reference human genome sequence, analysis methods have improved enormously, fostering the hope that biomarkers can be used to individualize therapies and offer precise treatment based on tumor and patient characteristics. Biomarkers at every level of the system (genetics, epigenetics, gene expression, micro-RNA, proteomics and others) can be used for this. This has led to changes in clinical study designs, with drug developments often only focusing on small or very small subgroups of patients and tumors. The screening and registration of patients and their molecular tumor data has therefore become very important for the successful completion of clinical studies. This new form of medicine presents particular challenges for patients and physicians. Even in this new age of genome-wide analysis, the focus should still be on the patients' quality of life. This review summarizes recent developments and describes how the PRAEGNANT study network manages the aforementioned medical challenges and changes to create a professional infrastructure for patients and physicians.

\section{Zusammenfassung \\ $\nabla$}

In den letzten Jahrzehnten sind zwar Fortschritte in der Behandlung des metastasierten Mammakarzinoms erzielt worden, jedoch orientieren sich nur wenige Therapien an den individuellen Eigenschaften der Patientin oder der Tumorerkrankung. Mehr als 10 Jahre nach der Veröffentlichung der menschlichen genetischen Sequenz haben sich die Analysemethoden dahingehend verbessert, dass große Hoffnung besteht, die Therapie weiterzuentwickeln und im Sinne einer „Präzisionsmedizin“ individuell für die Patientin und die Tumorerkrankung zu gestalten. Hierbei werden Biomarker auf jeder Ebene der Systembiologie herangezogen (Genetik, Epigenetik, Genexpression, micro-RNA, Proteomics und weitere). Diese Individualisierung hat zu einer neuen Generation von Studien geführt, sodass manche Arzneimittelentwicklungen nur noch für sehr kleine Patientinnen-Subgruppen durchgeführt werden. Die Organisation der Erfassung von Patientinnen und molekularen Tumordaten ist deswegen von besonderer Bedeutung für die erfolgreiche Durchführung von klinischen Studien. Diese neue Form der Medizin stellt eine besondere Herausforderung für Patientinnen und Ärzte dar. Der Erhalt der Lebensqualität sollte auch in diesem neuen Zeitalter der Medizin als zentrales Therapieziel im Fokus stehen. In diesem Übersichtsartikel werden wir die Entwicklungen der letzten Jahre aufzeigen und das PRAEGNANT-Studiennetzwerk vorstellen, welches die oben genannten Probleme und Ziele angeht und eine professionalisierte Infrastruktur hierfür aufbaut.

\footnotetext{
* Shared lead authorship
} 


\section{Introduction}

$\nabla$

As our understanding of breast cancer grows, it has become increasingly clear that it is possible not just to plan and assess the choice of therapy for patients with breast cancer but also the course of therapy using molecular and cellular tests [1]. Some therapies already treat patients based on the patient's specific genetic mutations and amplifications or gene expression patterns. However, most of these therapies are still being carried out in the context of research or clinical studies.

But new therapies for established patient and tumor characteristics are also emerging, with specific therapies developed for and aimed at particular subgroups of patients. The two most wellknown examples of this are hormone therapy and anti-HER2 therapy.

The clinical and scientific basis of this approach are outlined below. The focus is on breast cancer patients with metastatic disease. The research and care initiative PRAEGNANT will also be described. This initiative aims to create a basis which will make this type of medicine available to patients with metastatic breast cancer and their physicians even outside clinical studies.

\section{Prognostic and Predictive Factors in Metastatic Breast Cancer \\ $\nabla$}

The PRAEGNANT study program focuses on patients with advanced, incurable, metastatic breast cancer. There are a few clinical factors which could have a prognostic significance for patients with metastatic breast cancer, even if they are not yet used much in routine clinical practice. In routine practice, decisions on therapy tend to focus more on the overall clinical picture, the severity of symptoms according to the patient's subjective assessment, and the subjective assessment of how rapid remission needs to be.

Factors described in some studies as prognostic factors for breast cancer patients with metastatic disease include age, tumor mass, grading, time from primary diagnosis to metastasis, and the site of metastasis [2]. Molecular factors have also been associated with prognosis. Most studies have focused on the prognostic characteristics of the primary tumor and the prognosis for the patient after metastasis. Hormone receptor status, HER2 status and $\mathrm{Ki}-67$ are the most commonly investigated parameters [3]. However, tumor characteristics are known to change during the course of disease [4-11], and the recommendation to carry out bioptic evaluation of metastases to determine their molecular characteristics has therefore been included in national therapy recommendations [12]. But although obtaining tumor tissue from the breast is relatively uncomplicated, for practical reasons and to avoid complications physicians often object to taking biopsies of metastatic tissue. One of the aims of the PRAEGNANT study program is to carry out molecular tests in the setting of metastatic disease and to develop evaluation methods which can be carried out without requiring biopsies of metastatic tissue, for example by testing the patient's blood. Circulating tumor cells, circulating nucleic acids or other biomarkers could be used for this type of analysis.

\section{Molecular Patterns in Breast Cancer \\ $\nabla$}

Most of the current understanding of molecular patterns in breast cancer was gained from patients with primary breast cancer without metastatic disease. Most of the biomarkers listed below therefore refer to primary breast cancer.

As our knowledge of the human genome increases and the cost of genome-wide analysis decreases, the relationships between genetics, epigenetics, gene expression and protein functions are becoming clearer. The existence of molecular subgroups for breast cancer types and their prognostic relevance based on mRNA measurements were already discussed in the literature more than 10 years ago [13-15]. One classification differentiates between basal, luminal A, luminal B and HER2-enriched breast cancer subtypes. An attempt was subsequently made to classify these molecular subtypes using known histopathological characteristics [16-19]. Triple negative tumors (ER negative, PgR negative and HER2 negative) were found to most closely resemble basal tumors. Slow-proliferating (e.g. Ki-67 < 14\%) and hormone receptor-positive tumors generally correspond to luminal A tumors, while hormone receptor-positive tumors with high proliferation rates (e.g. Ki-67 > 14\%) are most closely correlated with luminal B tumors [20-22]. These cut-offs mirror the biological subtypes. However, other cut-offs (for example 20\%) are also being discussed in clinical practice [23].

The Human Genome Project and the publication of the human genome sequence [24-26] has created the basis for modern genome-wide analysis at various levels of systems biology. The biological interrelationships behind various diseases are gradually being - at least partially - uncovered. One of the next challenges in breast cancer research will be to obtain an understanding of why there are different patterns of breast cancer expression and why these may change during the course of disease. Genetic tumor factors probably play a role as could epigenetic patterns, micro-RNA and other, still unknown regulation mechanisms. Hereditary factors such as BRCA mutation or low-penetrance genetic variants are also known to affect gene expression in tumors [27].

\section{Genetic Factors}

$\nabla$

Various genetic germline mutations and somatic genetic mutations have been associated with tumor biology and the prognosis of breast cancers. Both mutations and structural and numerical changes to the tumor genome and germline genome could be relevant for the tumor biology of breast cancer.

\section{Mutations during pathogenesis}

Genetic tumor mutations have already been investigated by comparing mutations to unchanged DNA. The most extensive investigation in this context was the Cancer Genome Atlas (TCGA) [28]. In the TCGA the genetic information of unchanged reference DNA was compared to the DNA of breast cancer tumors. This resulted in the identification of the most common mutations occurring in breast cancer. The most common gene mutations in breast cancer found in the TCGA investigations were TP53, PIK3CA, GATA3, MAP3K1, MLL3, CDH1, MAP2K4, RUNX1, PTEN and others.

These initial investigations have already shown clear differences in mutation frequencies between different molecular subtypes classified according to their level of gene expression. Thus, a PI3K mutation was found in $32-49 \%$ of cases with luminal (A 
and B) and HER2-positive breast cancer but only in 7\% of cases with basal-like tumors [28]. This explains the current development of PI3K inhibitor drugs which focus on hormone receptorpositive and HER2-positive disease.

\section{Changes in the number of gene copies}

Another genetic tumor change can consist of an increase or decrease in the number of gene copies. In a large investigation carried out as part of the METABRIC study, the number of gene copies and the associated gene expressions were determined for every gene [29]. This allowed positions to be identified in the genome where changes in gene copy numbers and an associated change in gene expression occurred most commonly. Genes in which such changes occurred include ZNF703, PTEN, MYC, CCND1, MDM2, ERBB2, CCNE1, MDM1, MDM4, CDK3, CDK4, CAMK1D, PI4KB and NCOR1 (amplifications) and PPP2R2A, MTAP und MAP2K4 (deletions). The strongest association was found between amplification in the genes HER2 (ERBB2) and cyclin D1 (CCND1).

\section{Genetic variants as prognostic or predictive factors}

Some studies have tried to link the most common mutations listed above and gene copy alterations to prognosis, in other words, to link prognosis to these new biomarkers. Gene copy alterations and the associated changes in gene expression could be used to improve the evaluation of prognosis for known molecular subgroups [29]. But with the exception of HER2, none of these loci have been found to have any clinical relevance for prognostic evaluation or therapy planning.

With regard to mutations, it was found that mutations in PI3K are associated with a poorer response to anti-HER2 therapy in patients with HER2-positive tumors. Only $19.4 \%$ of patients with PI3K mutation had complete pathological remission compared to $32.8 \%$ of cases without mutation in this gene [30]. Nevertheless, mutation in PI3K was not found to be correlated to a different prognosis [30]. Similarly, no association between prognosis and mutations and amplifications was found in patients treated with the mTOR inhibitor everolimus [31].

Some genes whose mutation affects the efficacy of neoadjuvant aromatase inhibitor therapy have been identified (MAP3K1, PIK3CA, TP53, GATA3, CDH1, TBX3, ATR, RUNX1 and others), [32]. Considerable overlap was found between these genes and the genes described by the Cancer Genome Atlas [28,32].

A large-scale analysis of mutations in 83 genes done in a large population of hormone receptor-positive patients $(n=632)$ has provided more insight into the importance of mutations as prognostic markers [33]. The 83 genes were selected based on previous studies $[28,32,34]$ and sequenced in the patient population. In this analysis, mutation in the DDR1 (discoidin domain receptor tyrosine kinase 1) gene [33] was found to be correlated with prognosis.

It remains to be seen whether and which genes could be used as prognostic and predictive parameters based on their genetic alterations. Table 1 presents a number of such genes previously described in the literature $[28,32,34]$.

\section{Significance of genetic germline variants}

In addition to somatic variants, the relevance of hereditary germline mutations and variants for the prognosis of breast cancer are also being discussed.

A patient's genetic heredity can be associated with a specific molecular breast cancer subtype. The most famous examples of this are patients with the BRCA1 mutation. If a patient with the BRCA1 mutation develops breast cancer, the probability that this cancer will be triple negative is more than $50 \%[27,35,36]$. Other lowpenetrance genetic variants reported in the literature were also found to be associated with a specific molecular subtype [3745]. Some of them are similar to BRCA1 and BRCA2 in that they play important roles in both breast cancer and ovarian cancer [46-48]. Unsurprisingly, genetic variants have also been associated with prognosis and the overall survival of breast cancer patients [49-52]. The causes can be so wide-ranging that even the

Table 1 Genes whose mutations could potentially play a role in the pathogenesis or prognosis of breast cancer or affect the therapeutic efficacy of breast cancer treatment $[28,32,34]$.

\begin{tabular}{|c|c|c|c|c|c|}
\hline AFF2 & CREBBP & JAK2 & NCOR1 & PTPN22 & USH2A \\
\hline AGTR2 & CSF1R & KIT & NCOR2 & PTPRD & XBP1 \\
\hline AKT1 & CTCF & KRAS & NF1 & RB1 & \\
\hline AKT2 & DCAF4L2 & LCLAT1 & NOTCH4 & RB1CC1 & \\
\hline AKT3 & DDR1 & LTK & NRAS & RELN & \\
\hline ARID1A & EGFR & LYN & OR4N4 & RERG & \\
\hline ARID1B & ERBB2 & MAGI3 & OR6A2 & RPGR & \\
\hline ATM & ERBB3 & MALAT1 & PAPSS2 & RRM2 & \\
\hline ATR & ERBB4 & MAN2A2 & PDGFRA & RUNX1 & \\
\hline AURKA & ESR1 & MAP2K4 & PGM2 & RYR2 & \\
\hline BIRC6 & FBXW7 & MDM2 & PIK3CA & SEPT13 & \\
\hline BRAF & FOXA1 & MDM4 & PIK3R1 & SF3B1 & \\
\hline BRCA1 & FOXC1 & MED12 & PIN1 & SMARCD1 & \\
\hline BRCA2 & FRG1B & MET & PLD1 & SMG1 & \\
\hline CASP8 & FZD7 & MLL & POLR1A & TAB1 & \\
\hline CAV1 & GATA3 & MLL2 & PPP2R2A & TAB2 & \\
\hline CBFB & GPR32 & MLL3 & PRKCZ & TBL1XR1 & \\
\hline CCND3 & HEXA & MTAP & PRKDC & TBX3 & \\
\hline $\mathrm{CDH} 1$ & HMGCS2 & MTPR & PRKX & TGFB1 & \\
\hline CDKN1B & IDH3B & MYBB & PRLR & TGFB2 & \\
\hline CLCA1 & INSRR & MYBL2 & PRPS2 & TP53 & \\
\hline CLEC19A & JAK1 & NCOA3 & PTEN & TPH2 & \\
\hline
\end{tabular}


Table 2 Breast cancer studies which have integrated molecular tests in their study design or use them as predictors for the primary study goal $\left({ }^{*}\right.$ relevant for therapy or study means that the results of biomarker tests affected the choice of therapy or the study design over and above stratification or subgroup analysis; ${ }^{* *}$ in some of these studies, inoperable locally advanced disease was sufficient for inclusion in the study).

\begin{tabular}{|c|c|c|c|c|}
\hline Study name & Test & $\begin{array}{l}\text { Test results } \\
\text { relevant for } \\
\text { therapy or study* }\end{array}$ & Drug & Therapy setting \\
\hline BRIGHTNESS (NCT02032277) & $\begin{array}{l}\text { germline DNA testing } \\
\text { for BRCA } 1 / 2 \text { mutation }\end{array}$ & & veliparib & neoadjuvant \\
\hline Olympia (NCT02032823) & $\begin{array}{l}\text { germline DNA testing } \\
\text { for BRCA } 1 / 2 \text { mutation }\end{array}$ & $x$ & olaparib & $\begin{array}{l}\text { adjuvant/ } \\
\text { post-neoadjuvant }\end{array}$ \\
\hline EMBRACA (NCT01945775) & $\begin{array}{l}\text { germline DNA testing } \\
\text { for BRCA } 1 / 2 \text { mutation }\end{array}$ & $x$ & talazoparib & $\begin{array}{l}\text { 1st-3rd line } \\
\text { metastasized** }\end{array}$ \\
\hline ABRAZO (NCT02034916) & $\begin{array}{l}\text { germline DNA testing } \\
\text { for BRCA } 1 / 2 \text { mutation }\end{array}$ & $x$ & talazoparib & $\begin{array}{l}4 \text { th+ line } \\
\text { metastasized }\end{array}$ \\
\hline $\begin{array}{l}\text { Neoadjuvant BYL719 vs. BKM120 Study } \\
\text { (NCT01923168) }\end{array}$ & tumor PI3K testing & $x$ & $\begin{array}{l}\text { buparlisib (BKM120)/ } \\
\text { alpelisib (BYL719) }\end{array}$ & neodjuvant \\
\hline PRESENT (NCT01479244) & HLA testing/HER2 testing & $x$ & nelipepimut-S & adjuvant \\
\hline DETECT III/IV (NCT01619111) & $\begin{array}{l}\text { measurement of HER2 } \\
\text { and ER expression in CTCs }\end{array}$ & $\mathrm{x}$ & $\begin{array}{l}\text { lapatinib, everolimus, } \\
\text { eribulin }\end{array}$ & \\
\hline FERGI (NCT01437566) & tumor PI3K testing & & pictilisib & metastasized** \\
\hline BT062 (EudraCT No. 2013-003 252-20) & TNBC, CD138 expression & $x$ & indatuximab, ravtansine & metastasized \\
\hline $\begin{array}{l}\text { Belle 2/3/4 (NCT01610284, } \\
\text { NCT01633060, NCT01572727) }\end{array}$ & tumor PI3K testing & & buparlisib (BKM120) & metastasized** \\
\hline GLOW (NCT01202591) & tumor FGFR1 amplification & $x$ & AZD4547 & metastasized** \\
\hline ADAPT (NCT01817452, NCT01745965) & $\begin{array}{l}\text { 21-gene expression testing; } \\
\text { serial gene expression testing }\end{array}$ & $x$ & various & $\begin{array}{l}\text { neoadjuvant/ } \\
\text { adjuvant }\end{array}$ \\
\hline PreFace (NCT01908556) & genome-wide germline genotyping & & letrozole & adjuvant \\
\hline SUCCESS C (NCT00847444) & CTC determination & $\mathrm{x}$ & $\begin{array}{l}\text { exemestan/ } \\
\text { tamoxifen }\end{array}$ & adjuvant \\
\hline
\end{tabular}

detection of breast cancer can be associated with breast cancer progression. Risk genes associated with the molecular biology of breast cancer are directly linked to mammographic density and thus to the probability of being detected sooner or later on mammography screening [53-58].

Another reason could be that genetic variance is accociated with a change of drug efficacy. For a time, the discussion focused on whether CYP2D6 genotyping could identify patients in whom tamoxifen therapy would have only limited efficacy because the drug is not metabolized into its active metabolite. However, different studies came to contradictory results, and this approach was therefore not introduced into clinical practice [59-62].

Some studies are currently actively recruiting participants to investigate the efficacy of PARP inhibition in patients with BRCA1 or BRCA2 mutation [63-65] ( Table 2). This type of study presents new challenges because the therapies can only be made available to a small number of clearly defined patients.

\section{Circulating Tumor Cells and Circulating Tumor Nucleic Acids \\ $\nabla$}

Even though some hereditary genetic information can be useful when planning treatment, the determination of most biomarkers requires biopsies of tumor tissue. Because of this, attempts to find ways of determining tumor characteristics using blood are particularly interesting. Such novel analysis methods are known as "liquid biopsies".

The presence of circulating tumor cells (CTC) in plasma has been consistently associated with prognosis in patients with metastasized breast cancer [66-69]. The presence of CTCs was found to be an independent prognostic factor even in the non-metastatic setting [70]. The next logical step was to determine the molecular properties of circulating tumor cells $[71,72]$. Several clinical studies are currently looking at whether this could help with treatment planning and offer useful information for prognosis [73-76]. However, isolating the CTCs is still relatively expensive and time-consuming and requires large, cost-intensive equipment which is expensive to run.

A less expensive approach could be to analyze circulating nucleic acids. Tumor cells in the body release small amounts of DNA into the bloodstream, known as circulating DNA (ctDNA). This process was first described in 1948 [77,78]. But it is only now that new analysis methods offer the opportunity to use these circulating nucleic acids to research and potentially treat tumor disease. Various analyses can be carried out using ctDNA. They range from determination of known point mutations to the sequencing of entire genetic regions or the determination of gene copy mutations in specific genetic regions. Other genotyping methods are being developed. The genotyping of ctDNA could offer a relatively feasible way of analyzing genomic mutations which occur over the course of disease, with the findings used to measure disease progression or to evaluate the patient's response to treatment. One study, which carried out dynamic profiling of solid tumors, was able to show that mutations occur in tumors over the course of anti-hormonal treatment [79]. The study showed that molecular patterns of somatic mutations specifically alter the tumor's response to treatment and affect progression. Just how this could be used to plan and monitor treatment is not yet clear. But if such analyses in serum become possible, they could provide early indications about the efficacy of and the response to treatment. A few small studies have reported promising results with concordance between mutations found in tumors and those found in ctDNA from the same patient [80]. 


\section{Inclusion of Genetic Testing in Studies \\ $\nabla$}

Only two biomarkers are used in routine clinical practice to plan treatment for patients with breast cancer: HER2 status and hormone receptor status.

Some clinical studies have included or prospectively will include the determination of biomarkers (usually testing for mutations or to measure gene expression) in the study design ( $\bullet$ Table 2 ). Some studies demand specific test results as a prerequisite for inclusion in the study. Other studies use the test results for prospectively planned subgroup analysis and/or stratification.

The current PARP inhibitor studies are one example of studies which require a specific testing result. Most of these studies demand evidence of BRCA mutation for inclusion into the study. Some studies additionally only include patients with triple negative breast cancer.

Others studies have prospectively integrated test results into the treatment concept and randomization algorithms. The NNBC3 study used invasion factors uPA/PAI1 to determine which patients should receive adjuvant chemotherapy. More recent studies have used multi-gene tests. The ADAPT study concept used a 21-gene test and serial analysis of tumors to identify patients with an excellent prognosis for whom it was postulated that they did not require chemotherapy.

PI3K mutation testing is an example of studies where an analysis of projected subgroups is planned. Although the biological importance of PI3K mutations, particularly in HER2-positive and hormone receptor-positive breast cancer, is well established and there are indications that tumor response to anti-HER2 treatment depends on mutation status [30], it is still unclear whether the mutation can predict efficacy when the enzyme itself is inhibited. In fact, there is some initial evidence that mutation status did not predict efficacy as measured by progression-free survival in patients treated with the PI3K inhibitor pictilisib [81].

The range of molecular tests included in clinical studies has increased in recent years. A number of studies completed or still underway in Germany have been listed in $\bullet$ Table 2.

\section{The PRAEGNANT Study (NCT02338167)}

The PRAEGNANT study network (Prospective Academic Translational Research Network for the Optimization of Oncological Health Care Quality in the Advanced Therapeutic Setting) was set up in Germany to take account of some of the recent rapid developments in molecular medicine in the treatment of patients with metastatic breast cancer.

Given all of the above, the PRAEGNANT study concept was set up for the following reasons:

- To carry out molecular tests under study conditions.

- To identify suitable breast cancer patients for clinical drug trials based on molecular testing.

- To identify breast cancer patients suitable for clinical drug trials based on conventional clinical inclusion criteria.

- To record treatment-induced toxicities and patient's quality of life in routine clinical practice.

- To record, show and benchmark the reality of medical care provided to patients with advanced metastatic breast cancer.
Table 3 First analysis of treatment lines and the time from diagnosis to metastasis or advanced loco-regional disease after inclusion of the first 244 patients.

\begin{tabular}{|c|c|c|c|}
\hline $\begin{array}{l}\text { Line of } \\
\text { treatment }\end{array}$ & $\begin{array}{l}\text { No. of } \\
\text { patients }\end{array}$ & $\begin{array}{l}\text { Time from diagnosis } \\
\text { to metastasis in } \\
\text { years (mean) }\end{array}$ & $\begin{array}{l}\text { Standard } \\
\text { deviation }\end{array}$ \\
\hline 1 & 114 & 4.3 & 7.2 \\
\hline 2 & 51 & 4.9 & 6.6 \\
\hline 3 & 32 & 5.5 & 7.1 \\
\hline 4 & 14 & 5.9 & 8.5 \\
\hline 5 & 11 & 5.0 & 5.2 \\
\hline $6+$ & 19 & 5.6 & 7.0 \\
\hline Unknown & 3 & 7.3 & 3.5 \\
\hline Total & 244 & 4.8 & 7.0 \\
\hline
\end{tabular}

Patient population, planned sample size and course of the study

Inclusion in this study concept is not limited to patients receiving specific treatment lines. All breast cancer patients who have either metastasis or inoperable loco-regional disease can be included in the study, irrespective of the treatment line they are receiving. Disease progression must be objectively evaluable. Analysis of the first 244 patients included in this study resulted in the distribution shown in Table 3 . Almost $50 \%$ of patients were receiving first-line treatment for metastatic disease.

Tumor re-evaluation is done every $2-3$ months, with additional assessments carried out if disease continues to progress and after every change of treatment ( $\nabla$ Fig. 1). Adverse Events and Severe Adverse Events are continually reported throughout the study as is quality of life, and a program (PRO; Patient-reported Outcomes) is used which allows patients to document their quality of life themselves together with any Adverse Events.

The study aims to include a total study population of around $\mathbf{3 2 0 0}$ patients. This should ensure that approximately 150 patients receiving first-line and 150 patients receiving second-line treatment in the metastatic setting will be included in the study for every molecular subtype, even for rare subtypes with a prevalence of only $10 \%$. This should provide a good insight into the prognosis and the quality of life of these patient groups.

\section{Using research findings}

Many current studies use specific clinical or molecular characteristics as inclusion criteria for patients in specific studies (cf. $\odot$ Table 2). Moreover, some studies require specific prior treatment and a specific progression over time before patients are included in the study. The PRAEGNANT study should be utilized to carry out investigations using the available biomaterials obtained in the study. As part of the analysis of this biomaterial, patients will be evaluated to see whether they are suitable for recruitment into particular studies. The patients will be informed of this at the start of recruitment into the PRAEGNANT study and can give their consent to being informed by their physician if they are found to be suitable for inclusion in other studies. This applies not only to molecular requirements but also to clinical parameters. Ideally, the patient is then referred to a center in the PRAEGNANT network where a specific study is being carried out. It is planned that around $\mathbf{4 0}$ centers will be participating, which will allow prior treatment to be compared between centers. There are almost no guidelines about the order in which various therapeutic agents should be used in the metastatic setting. Clin- 


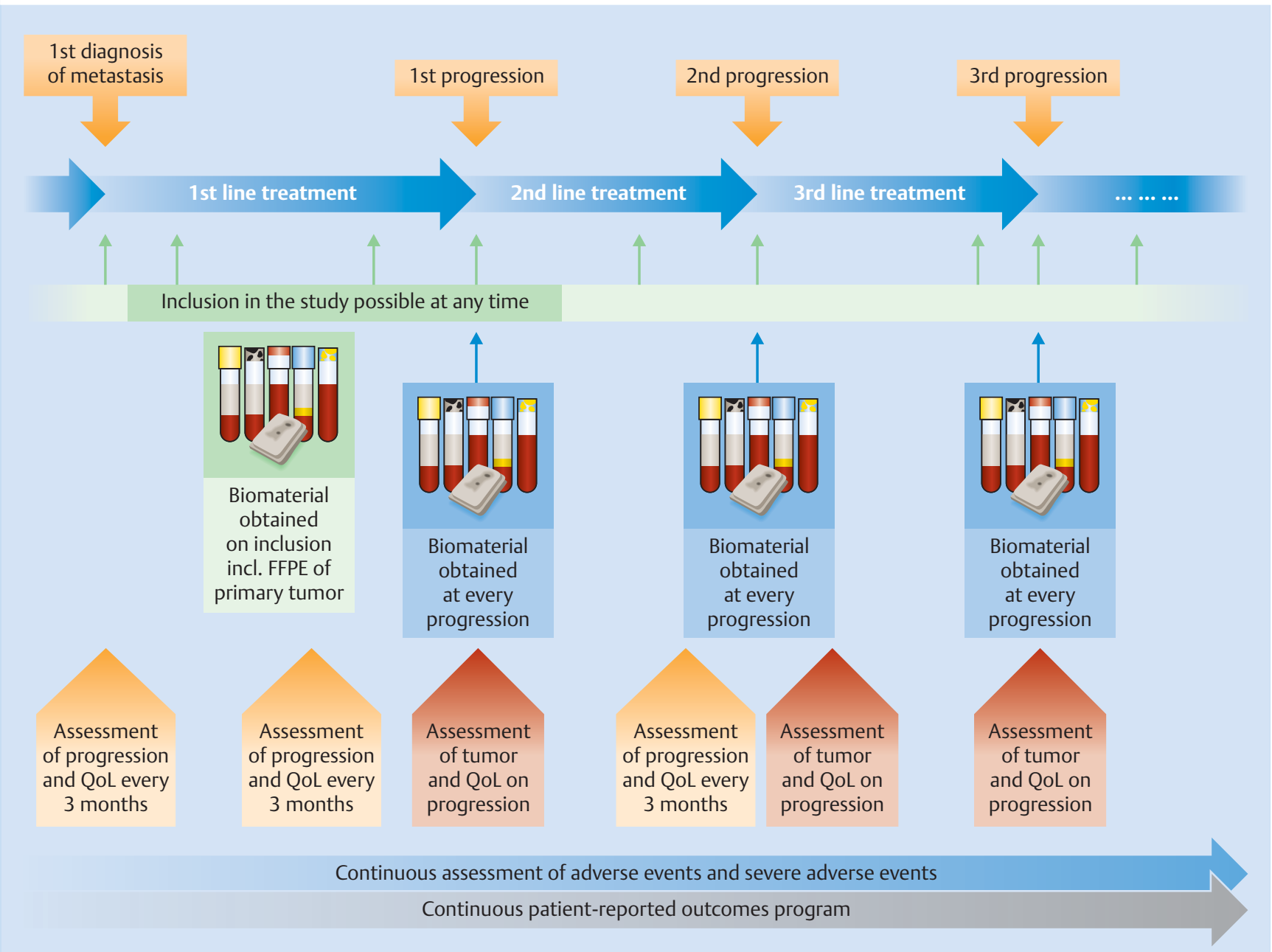

Fig. 1 Diagram of the PRAEGNANT study with regard to disease progression, inclusion in the study, blood sampling, tumor assessment and assessment of progression.

ical studies require specific prior treatments as the prerequisite for inclusion in the study. The information which the PRAEGNANT study will collect can be used in various ways. Centers can be given feedback if the treatment they provide does not fulfil the conditions of current studies. Cooperating centers carrying out studies can be informed about treatments currently used in clinical practice, allowing the cooperating centers to adapt their inclusion and exclusion criteria - where possible - to standard treatment practice.

\section{Using the network to exchange knowledge}

The aim is to use the information obtained and collected to record differences in care between the participating centers and to encourage a discussion about these differences. Patients could be included in this evaluation through the use of Patient-reported Outcomes (PRO) and specific information should be shared with the patient. In this information age, data collection should not simply be used to generate study data but also to provide direct and immediate benefits to the patient and the participating centers through the documentation and collection of data.
Using the study to show quality of life under real-life conditions

In Germany and other countries, after approval has been granted, as part of the approval process the authorities often demand evidence based on standard treatment practice that the study results are confirmed with regard to efficacy and quality of life. This is precisely the type of data the PRAEGNANT study will collect and evaluate. Patients will complete validated questionnaires on quality of life at regular intervals. Substudies will continue to investigate issues of treatment compliance, nutrition and exercise and look at health economics and pharmacoeconomics. The data will be used for assessment, evaluated to allow comparisons with clinical studies and made publicly available. The recording of Adverse Events is of particular interest in this context because for many new medications physicians only learn the best way of recording possible side-effects during approval studies. A higher incidence of problems and more significant clinical problems are noted more often in the post-approval setting than in approval studies. The musculoskeletal symptoms experienced during treatment with aromatase inhibitors are a well-known example of this. Another example is stomatitis in patients receiving everolimus; the incidence of stomatitis initially appeared to increase in clinical practice but then decreased again as administration of 


\begin{tabular}{|l|l|l|}
\hline $\begin{array}{l}\text { Plasma } \\
\text { Serum }\end{array}$ & $\begin{array}{l}\text { Protein analysis } \\
\text { Permline } \\
\text { DNA }\end{array}$ & $\begin{array}{l}\text { Chromosomal aberrations, mutations, } \\
\text { amplifications, deletions }\end{array}$ \\
\hline Micro-RNA & $\begin{array}{l}\text { Quantity, pattern, association with expression } \\
\text { and protein analysis }\end{array}$ \\
\hline $\begin{array}{l}\text { Circulating } \\
\text { tumor DNA }\end{array}$ & $\begin{array}{l}\text { Chromosomal aberrations, mutations, } \\
\text { amplifications, deletions }\end{array}$ \\
$\begin{array}{l}\text { Leukocyte } \\
\text { RNA }\end{array}$ & $\begin{array}{l}\text { Leukocyte RNA expression } \\
\text { CTCs }\end{array}$ & $\begin{array}{l}\text { Chromosomal aberrations, mutations, } \\
\text { amplifications, deletions, RNA expression, } \\
\text { protein analysis, cell cultures }\end{array}$ \\
\hline FFPE & DNA analysis, RNA analysis, protein analysis \\
\hline
\end{tabular}

Fig. 2 Analyses planned for breast cancer patients enrolled in the PRAEGNANT study. everolimus continued, possible because of improved prophylactic measures [82]. It is effects such as these that the PRAEGNANT study aims to record.

\section{Patient-reported Outcomes (PRO)}

In clinical studies, assessment of the patient's health is usually done by the physician. The patients themselves only complete validated questionnaires on their quality of life. Although this approach ensures a certain degree of objectivity when documenting side-effects, for example, the requirement of visits at regular intervals and the dependence on the motivation of the medical staff could also result in a poorer quality or otherwise affect the quality of the documentation. Modern, internet-based interaction portals can react flexibly to the documentation requirements of studies and patients. Various PRO modules covering areas such as quality of life, compliance to treatment, exercise, nutrition, Adverse Events and others will be tested and validated in the PRAEGNANT study.

\section{Database concept}

The PRAEGNANT study network uses an Oracle-based database with an eCRF format. It fulfils all the requirements for use by clinical studies (visit-based, recording of AEs and SAEs, audit trail ...). Monitoring of all data is done using a professional query verification and source data verification system. What distinguishes the PRAEGNANT network from most other multicenter studies is that the participating centers can download their center-specific data at any time during the project and use it for scientific research themselves.

\section{Biomaterial collection}

The collection of biomaterials plays a central role in the PRAEGNANT study network. The obtained biomaterials will be used to carry out high-level analyses which are relevant for the patient. These include both testing of the primary tumor and the metastasis and testing of biomaterials obtained from blood ( $\bullet$ Figs. 1 and 2).

Extensive blood samples will be taken from every patient on inclusion in the study, at each point of disease progression and/or every 3 months ( Fig. 1). Patients will additionally be asked whether they will permit the analysis of archived tumor samples (primary tumor and metastasis) for research purposes ( $\bullet$ Fig. 1). Blood samples include cannula to obtain serum, plasma, microRNA, leukocyte RNA, CTCs, ctDNA and germline DNA. In addition, procedures which specify how biomaterials obtained in multicenter studies should be sent to a central laboratory without endangering the quality of the investigation will be optimized. Patients will additionally be requested to sign over part of the tumor material from the primary tumor and from the biopsies of metastases to the study. The tumor block will be requested by the respective pathologist and re-evaluated using $\mathrm{H} \& \mathrm{E}$ slides, and recuts will be made for archiving and RNA and DNA extraction. In addition, a tissue micro-array (TMA) will be created from the tumor block. The PRAEGNANT study network is thus ideally positioned to carry out the analyses described above for patients and for existing studies.

\section{Conclusion}

$\nabla$

More than 10 years after the human genome was decoded, molecular analysis is being included in routine clinical practice and particularly in the design of clinical studies. The complexity of these analyses and the size of the subgroups defined by such analysis means that care networks, research networks and study networks must join forces to ensure that patients receive the best possible care and to ensure that it will continue to be possible to develop drugs even for small groups of patients. This is the goal that the PRAEGNANT study network has set itself for patients with metastatic breast cancer.

\section{Acknowledgements \\ $\nabla$}

This study is supported by research grants from the companies Novartis, Celgene and Roche. In addition, it receives support from TRR (Translational Research Resources) of the Gynecological and Obstetrical Department of the University Hospital Erlangen. 


\section{Conflict of Interest}

$\nabla$

PAF received honoraria from Amgen, Celgene, Roche, Pfizer, Genomic Health, Novartis, Teva and carried out research for Novartis and Amgen. MPL received honoraria from Roche, Novartis and Celgene. HT received honoraria from Novartis, $\mathrm{PH}$ received honoraria from Amgen, Roche, Pfizer and Novartis. EB carried out research for Novartis, Roche, Celgene and Bristol-Myers Squibb. All other authors of this study declare no conflict of interest.

\section{Affiliations}

${ }^{1}$ Frauenklinik des Universitätsklinikums Erlangen, Comprehensive Cancer Center Erlangen-EMN, Friedrich-Alexander Universität Erlangen-Nürnberg, Erlangen

2 Universitäts-Frauenklinik, Department für Frauengesundheit, Universitätsklinikum Tübingen, Eberhard Karls Universität Tübingen, Tübingen

${ }^{3}$ Forschungsinstitut für Frauengesundheit, Department für Frauengesundheit, Universitätsklinikum Tübingen, Eberhard Karls Universität Tübingen, Tübingen

${ }^{4}$ Universitäts-Frauenklinik Düsseldorf, Heinrich-Heine Universität Düsseldorf, Düsseldorf

5 Oncologianova GmbH Recklinghausen, Recklinghausen

6 Universitätsfrauenklinik Ulm, Ulm

7 Universitätsfrauenklinik Heidelberg, Ruprecht-Karls-Universität Heidelberg, Heidelberg

${ }^{8}$ Krankenhaus Nordwest, Klinik für Gynäkologie und Geburtshilfe, Frankfurt am Main

${ }^{9}$ Clin-Sol GmbH, Würzburg

${ }^{10}$ Unit of Biostatistics, Department of Gynecology and Obstetrics, University Hospital Erlangen, Friedrich-Alexander-University Erlangen-Nuremberg, Erlangen

${ }^{11}$ Medizinische Klinik mit Schwerpunkt Hämatologie und Onkologie; Charité Campus Benjamin Franklin Berlin, Berlin

12 Abteilung Gynäkologie und Geburtshilfe, Klinikum rechts der Isar, Technische Universität München, Munich

13 Klinik für Gynäkologie, Universitätsklinikum Hamburg-Eppendorf, Hamburg

14 Onkologie Bethanien, Frankfurt am Main

15 Studienleitung PRAEGNANT-Studie

${ }^{16}$ Nationales Centrum für Tumorerkrankungen, Heidelberg

17 Wissenschaftliche Leitung PRAEGNANT-Studiennetzwerk

\section{References}

1 Lux MP, Maass N, Schutz F et al. Breast cancer 2013 - interpretation of new and known data. Geburtsh Frauenheilk 2013; 73: 584-598

2 Largillier R, Ferrero JM, Doyen J et al. Prognostic factors in 1,038 women with metastatic breast cancer. Ann Oncol 2008; 19: 2012-2019

3 Loehberg CR, Almstedt K, Jud SM et al. Prognostic relevance of Ki-67 in the primary tumor for survival after a diagnosis of distant metastasis. Breast Cancer Res Treat 2013; 138: 899-908

4 Bogina G, Bortesi L, Marconi M et al. Comparison of hormonal receptor and HER-2 status between breast primary tumours and relapsing tumours: clinical implications of progesterone receptor loss. Virchows Arch 2011; 459: 1-10

5 Duchnowska R, Dziadziuszko R, Trojanowski T et al. Conversion of epidermal growth factor receptor 2 and hormone receptor expression in breast cancer metastases to the brain. Breast Cancer Res 2012; 14: R119

6 Hoefnagel LD, van de Vijver MJ, van Slooten HJ et al. Receptor conversion in distant breast cancer metastases. Breast Cancer Res 2010; 12: R75

7 Hoefnagel LD, Moelans CB, Meijer SL et al. Prognostic value of estrogen receptor $\alpha$ and progesterone receptor conversion in distant breast cancer metastases. Cancer 2012; 118: 4929-4935

8 Gong Y, Han EY, Guo $M$ et al. Stability of estrogen receptor status in breast carcinoma: a comparison between primary and metastatic tumors with regard to disease course and intervening systemic therapy. Cancer 2011; 117: 705-713

9 Fabi A, Di Benedetto A, Metro G et al. HER2 protein and gene variation between primary and metastatic breast cancer: significance and impact on patient care. Clin Cancer Res 2011; 17: 2055-2064

10 Wilking U, Karlsson E, Skoog L et al. HER2 status in a population-derived breast cancer cohort: discordances during tumor progression. Breast Cancer Res Treat 2011; 125: 553-561

11 Simon R, Nocito A, Hubscher T et al. Patterns of her-2/neu amplification and overexpression in primary and metastatic breast cancer. J Natl Cancer Inst 2001; 93: 1141-1146
12 Kommission Mamma der Arbeitsgemeinschaft für Gynäkologische Onkologie (AGO-Mamma). Diagnosis and treatment of patients with primary and metastatic breast cancer. Online: http://wwwago-onlinede/de/ infothek-fuer-aerzte/leitlinienempfehlungen/mamma/maerz-2013/ 2014; Last update: 28.03.2014; last access: 05.01.2015

13 Perou CM, Sorlie T, Eisen MB et al. Molecular portraits of human breast tumours. Nature 2000; 406: 747-752

14 van de Vijver MJ, He YD, van't Veer $L J$ et al. A gene-expression signature as a predictor of survival in breast cancer. N Engl J Med 2002; 347: 1999-2009

15 Schmidt M, Fasching PA, Beckmann MW et al. Biomarkers in breast cancer - an update. Geburtsh Frauenheilk 2012; 72: 819-832

16 Blows FM, Driver KE, Schmidt MK et al. Subtyping of breast cancer by immunohistochemistry to investigate a relationship between subtype and short and long term survival: a collaborative analysis of data for 10,159 cases from 12 studies. PLoS Med 2010; 7: e1000279

17 Ali AM, Provenzano E, Bartlett JM et al. Prognosis of early breast cancer by immunohistochemistry defined intrinsic sub-types in patients treated with adjuvant chemotherapy in the NEAT/BR9601 trial. Int J Cancer 2013; 133: 1470-1478

18 Sotiriou C, Pusztai L. Gene-expression signatures in breast cancer. N Engl J Med 2009; 360: 790-800

19 Sotiriou C, Wirapati P, Loi S et al. Gene expression profiling in breast cancer: understanding the molecular basis of histologic grade to improve prognosis. J Natl Cancer Inst 2006; 98: 262-272

20 Cheang MC, Chia SK, Voduc D et al. Ki67 index, HER2 status, and prognosis of patients with luminal B breast cancer. J Natl Cancer Inst 2009; 101: 736-750

21 Fasching PA, Heusinger K, Haeberle L et al. Ki67, chemotherapy response, and prognosis in breast cancer patients receiving neoadjuvant treatment. BMC Cancer 2011; 11: 486

22 Keam B, Im SA, Lee KH et al. Ki-67 can be used for further classification of triple negative breast cancer into two subtypes with different response and prognosis. Breast Cancer Res 2011; 13: R22

23 Yerushalmi R, Woods R, Ravdin PM et al. Ki67 in breast cancer: prognostic and predictive potential. Lancet Oncol 2010; 11: 174-183

24 Venter JC, Adams MD, Myers EW et al. The sequence of the human genome. Science 2001; 291: 1304-1351

25 Lander ES, Linton LM, Birren $B$ et al. Initial sequencing and analysis of the human genome. Nature 2001; 409: 860-921

261000 Genomes Project Consortium, Abecasis GR, Auton A et al. An integrated map of genetic variation from 1,092 human genomes. Nature 2012; 491: 56-65

27 Fasching PA, Ekici AB, Wachter DL et al. Breast cancer risk - from genetics to molecular understanding of pathogenesis. Geburtsh Frauenheilk 2013; 73: 1228-1235

28 Cancer Genome Atlas Network. Comprehensive molecular portraits of human breast tumours. Nature 2012; 490: 61-70

29 Curtis C, Shah SP, Chin SF et al. The genomic and transcriptomic architecture of 2,000 breast tumours reveals novel subgroups. Nature 2012; 486: 346-352

30 Loibl S, von Minckwitz G, Schneeweiss A et al. PIK3CA mutations are associated with lower rates of pathologic complete response to anti-human epidermal growth factor receptor 2 (her2) therapy in primary HER2-overexpressing breast cancer. J Clin Oncol 2014; 32: 3212-3220

31 Baselga J, Piccart M, Gnant $M$ et al. Minimal molecular alteration in PI3KCA, FGFR1 and CCND1 is associated with increased benefit from everolimus in hormone receptor-positive, HER2-advanced breast cancer: Insights from the BOLERO-2 trial. Eur J Cancer 2013; 49: S404S405

32 Ellis MJ, Ding L, Shen D et al. Whole-genome analysis informs breast cancer response to aromatase inhibition. Nature 2012; 486: 353-360

33 Griffith OL, Griffith M, Luo J et al. Prognostic effects of gene mutation in estrogen receptor positive breast cancer. San Antonio Breast Cancer Symposium 2014; Abstract No. S1-02

34 Shah SP, Roth A, Goya R et al. The clonal and mutational evolution spectrum of primary triple-negative breast cancers. Nature 2012; 486: 395-399

35 Couch FJ, Hart SN, Sharma P et al. Inherited mutations in 17 breast cancer susceptibility genes among a large triple-negative breast cancer cohort unselected for family history of breast cancer. J Clin Oncol 2014; DOI: $10.1200 / J C O .2014 .57 .1414$

36 Lakhani SR, Reis-Filho JS, Fulford L et al. Prediction of BRCA1 status in patients with breast cancer using estrogen receptor and basal phenotype. Clin Cancer Res 2005; 11: 5175-5180 
37 Fasching PA, Weihbrecht S, Haeberle L et al. HER2 and TOP2A amplification in a hospital-based cohort of breast cancer patients: associations with patient and tumor characteristics. Breast Cancer Res Treat 2014; 145: 193-203

38 Broeks A, Schmidt MK, Sherman ME et al. Low penetrance breast cancer susceptibility loci are associated with specific breast tumor subtypes: findings from the Breast Cancer Association Consortium. Hum Mol Genet 2011; 20: 3289-3303

39 Purrington KS, Slager S, Eccles D et al. Genome-wide association study identifies 25 known breast cancer susceptibility loci as risk factors for triple negative breast cancer. Carcinogenesis 2014; 35: 1012-1019

40 Stevens KN, Fredericksen Z, Vachon CM et al. 19p13.1 is a triple negative-specific breast cancer susceptibility locus. Cancer Res 2012; 72: 1795-1803

41 Garcia-Closas M, Couch FJ, Lindstrom S et al. Genome-wide association studies identify four ER negative-specific breast cancer risk loci. Nat Genet 2013; 45: 392-398

42 Milne RL, Benitez J, Nevanlinna $\mathrm{H}$ et al. Risk of estrogen receptor-positive and -negative breast cancer and single-nucleotide polymorphism 2q35-rs13387042. J Natl Cancer Inst 2009; 101: 1012-1018

43 Figueroa JD, Garcia-Closas M, Humphreys $M$ et al. Associations of common variants at $1 \mathrm{p} 11.2$ and 14q24.1 (RAD51L1) with breast cancer risk and heterogeneity by tumor subtype: findings from the Breast Cancer Association Consortium. Hum Mol Genet 2011; 20: 4693-4706

44 French JD, Ghoussaini M, Edwards SL et al. Functional variants at the $11 \mathrm{q} 13$ risk locus for breast cancer regulate cyclin D1 expression through long-range enhancers. Am J Hum Genet 2013; 92: 489-503

45 Stevens KN, Vachon CM, Lee AM et al. Common breast cancer susceptibility loci are associated with triple-negative breast cancer. Cancer Res 2011; 71: 6240-6249

46 Fasching PA, Gayther S, Pearce L et al. Role of genetic polymorphisms and ovarian cancer susceptibility. Mol Oncol 2009; 3: 171-181

47 Bolton KL, Tyrer J, Song $H$ et al. Common variants at 19p13 are associated with susceptibility to ovarian cancer. Nat Genet 2010; 42: 880884

48 Antoniou AC, Wang X, Fredericksen ZS et al. A locus on 19p13 modifies risk of breast cancer in BRCA1 mutation carriers and is associated with hormone receptor-negative breast cancer in the general population. Nat Genet 2010; 42: 885-892

49 Fasching PA, Loehberg $C R$, Strissel PL et al. Single nucleotide polymorphisms of the aromatase gene (CYP19A1), HER2/neu status, and prognosis in breast cancer patients. Breast Cancer Res Treat 2008; 112: 89-98

50 Azzato EM, Tyrer J, Fasching PA et al. Association between a germline OCA2 polymorphism at chromosome 15q13.1 and estrogen receptornegative breast cancer survival. J Natl Cancer Inst 2010; 102: 650-662

51 Fasching PA, Pharoah PD, Cox A et al. The role of genetic breast cancer susceptibility variants as prognostic factors. Hum Mol Genet 2012; 21: 3926-3939

52 Weischer M, Nordestgaard BG, Pharoah P et al. CHEK2*1100delC heterozygosity in women with breast cancer associated with early death, breast cancer-specific death, and increased risk of a second breast cancer. J Clin Oncol 2012; 30: 4308-4316

53 Vachon CM, Scott CG, Fasching PA et al. Common breast cancer susceptibility variants in LSP1 and RAD51L1 are associated with mammographic density measures that predict breast cancer risk. Cancer Epidemiol Biomarkers Prev 2012; 21: 1156-1166

54 Lindstrom S, Thompson DJ, Paterson AD et al. Genome-wide association study identifies multiple loci associated with both mammographic density and breast cancer risk. Nat Commun 2014; 5: 5303

55 Fasching PA, Heusinger K, Loehberg CR et al. Influence of mammographic density on the diagnostic accuracy of tumor size assessment and association with breast cancer tumor characteristics. Eur J Radiol 2006; 60: 398-404

56 Heusinger K, Jud SM, Haberle $L$ et al. Association of mammographic density with hormone receptors in invasive breast cancers: results from a case-only study. Int J Cancer 2012; 131: 2643-2649

57 Heusinger K, Jud SM, Haberle L et al. Association of mammographic density with the proliferation marker Ki-67 in a cohort of patients with invasive breast cancer. Breast Cancer Res Treat 2012; 135: 885-892

58 Hack CC, Haberle L, Geisler K et al. Mammographic density and prediction of nodal status in breast cancer patients. Geburtsh Frauenheilk 2013; 73: 136-141
59 Murdter TE, Schroth W, Bacchus-Gerybadze L et al. Activity levels of tamoxifen metabolites at the estrogen receptor and the impact of genetic polymorphisms of phase I and II enzymes on their concentration levels in plasma. Clin Pharmacol Ther 2011; 89: 708-717

60 Schroth W, Hamann U, Fasching PA et al. CYP2D6 polymorphisms as predictors of outcome in breast cancer patients treated with tamoxifen: expanded polymorphism coverage improves risk stratification. Clin Cancer Res 2010; 16: 4468-4477

61 Schroth W, Goetz MP, Hamann U et al. Association between CYP2D6 polymorphisms and outcomes among women with early stage breast cancer treated with tamoxifen. JAMA 2009; 302: 1429-1436

62 Province MA, Goetz MP, Brauch H et al. CYP2D6 genotype and adjuvant tamoxifen: meta-analysis of heterogeneous study populations. Clin Pharmacol Ther 2014; 95: 216-227

63 Robson ME, Tutt A, Balmaña J et al. OlympiA, Neo-Olympia and OlympiAD: randomized phase III trials of olaparib in patients (pts) with breast cancer (BC) and a germline BRCA1/2 mutation (gBRCAm). San Antonio Breast Cancer Symposium 2014; Abstract No. OT1-1-04

64 Turner NC, Balmana J, Domchek SM et al. A phase 2, 2-stage, 2-cohort study of the oral PARP inhibitor BMN 673 in patients with germline BRCA mutation and locally advanced and/or metastatic breast cancer (ABRAZO study). San Antonio Breast Cancer Symposium 2014; Abstract No. OT1-1-14

65 Litton JK, Blum JL, Eiermann W et al. A phase 3, open-label, randomized, parallel, 2-arm multi-center study of the oral PARP inhibitor BMN 673 versus physician's choice in germline BRCA mutation subjects with locally advanced and/or metastatic breast cancer (EMBRACA study). San Antonio Breast Cancer Symposium 2014; Abstract No. OT1-1-12

66 Muller V, Riethdorf S, Rack B et al. Prognostic impact of circulating tumor cells assessed with the CellSearch System and AdnaTest Breast in metastatic breast cancer patients: the DETECT study. Breast Cancer Res 2012; 14: R118

67 Wallwiener M, Hartkopf AD, Baccelli I et al. The prognostic impact of circulating tumor cells in subtypes of metastatic breast cancer. Breast Cancer Res Treat 2013; 137: 503-510

68 Bidard FC, Peeters DJ, Fehm T et al. Clinical validity of circulating tumour cells in patients with metastatic breast cancer: a pooled analysis of individual patient data. Lancet Oncol 2014; 15: 406-414

69 Cristofanilli M, Budd GT, Ellis MJ et al. Circulating tumor cells, disease progression, and survival in metastatic breast cancer. $\mathrm{N}$ Engl J Med 2004; 351: 781-791

70 Rack B, Schindlbeck C, Juckstock J et al. Circulating tumor cells predict survival in early average-to-high risk breast cancer patients. J Natl Cancer Inst 2014; DOI: 10.1093/jnci/dju066

71 Fehm T, Becker S, Duerr-Stoerzer S et al. Determination of HER2 status using both serum HER2 levels and circulating tumor cells in patients with recurrent breast cancer whose primary tumor was HER2 negative or of unknown HER2 status. Breast Cancer Res 2007; 9: R74

72 Fehm T, Muller V, Aktas B et al. HER2 status of circulating tumor cells in patients with metastatic breast cancer: a prospective, multicenter trial. Breast Cancer Res Treat 2010; 124: 403-412

73 Melcher CA, Janni W, Rack B et al. DETECT III - a multicenter, randomized, phase III study to compare standard therapy alone versus standard therapy plus lapatinib in patients with initially HER2-negative metastatic breast cancer and HER2-positive circulating tumor cells. Eur J Cancer 2012; 48: S95-S96

74 Hagenbeck C, Melcher CA, Janni JW et al. DETECT III: a multicenter, randomized, phase III study to compare standard therapy alone versus standard therapy plus lapatinib in patients (pts) with initially HER2negative metastatic breast cancer but with HER2-positive circulating tumor cells (CTC). J Clin Oncol 2012; 30 (Suppl.): Abstr. TPS1146

75 Melcher C, Schochter F, Albrecht S et al. DETECT IV - a multicenter, single arm, phase II study evaluating the efficacy of Everolimus in combination with endocrine therapy in patients with HER2-negative, hormone-receptor positive metastatic breast cancer and exclusively HER2-negative circulating tumor cells (CTCs). Oncol Res Treat 2014; 37: 29-29

76 Albrecht S, Schochter F, Melcher C et al. DETECT III - a multicenter, randomized, phase III trial to assess efficacy of lapatinib in patients with HER2-negative metastatic breast cancer and HER2-positive circulating tumor cells (CTCs). Oncol Res Treat 2014; 37: 29-29

77 Mandel $P$, Metais $P$. Les acides nucleiques du plasma sanguin chez l'homme. C R Seances Soc Biol Fil 1948; 142: 241-243 
78 Haber DA, Velculescu VE. Blood-based analyses of cancer: circulating tumor cells and circulating tumor DNA. Cancer Discov 2014; 4: 650661

79 Dixon JM, Turnbull AK, Fan C et al. In-depth genomic analysis of ER+ breast cancers during development of endocrine resistance. San Antonio Breast Cancer Symposium 2014; Abstract No. S1-05

80 Rothe F, Laes JF, Lambrechts D et al. Plasma circulating tumor DNA as an alternative to metastatic biopsies for mutational analysis in breast cancer. Ann Oncol 2014; 25: 1959-1965
81 Krop I, Johnston S, Mayer IA et al. The FERGI phase II study of the PI3 K inhibitor pictilisib (GDC-0941) plus fulvestrant vs. fulvestrant plus placebo in patients with ER+, aromatase inhibitor (AI)- resistant advanced or metastatic breast cancer. San Antonio Breast Cancer Symposium 2014; Abstract No. S2-02

82 Fasching PA, Decker T, Schneeweiss A et al. Breast cancer treatment with everolimus and exemestane for ER+ women - Results of the 2nd interim analysis of the non-interventional trial BRAWO. European Society of Medical Oncology Meeting (ESMO). 2014; Abstract No. LBA9 